\title{
KOMPARASI PROBLEM POSING DAN SOLVING TERHADAP KEMAMPUAN BERPIKIR KRITIS DITINJAU DARI SELF CONFIDENCE
}

\author{
Egy Purwanda ${ }^{1}$, Ahmad Yani $\mathbf{T}^{2}$, Utin Desy Susiaty ${ }^{3}$ \\ Program Studi Pendidikan Matematika, IKIP-PGRI Pontianak ${ }^{1,3}$ \\ Program Studi Pendidikan Matematika, Universitas Tanjungpura Pontianak ${ }^{2}$ \\ Email : egypurwanda789@gmail.com ${ }^{1}$
}

\begin{abstract}
Abstrak
Tujuan penelitian ini untuk melihat komparasi model pembelajaran Problem Posing dan Problem Solving terhadap kemampuan berpikir kritis ditinjau dari Self Confidence siswa dalam materi fungsi. Metode penelitian adalah eksperimen, dengan bentuk Quasi Eksperimen Design, dengan desain factorial 2x3. Populasi penelitian seluruh siswa kelas VIII SMP Negeri 3 Sanggau Ledo TA. 2019/2020 yang terdiri dari 3 kelas, yang menggunakan teknik Cluster Random Sampling. Teknik analisis data penelitian analisis variansi dua jalan sel tak sama dan disimpulkan bahwa (1) model pembelajaran Problem Posing memberikan kemampuan berpikir kritis yang lebih baik daripada Problem Solving; (2) siswa dengan self confidence tinggi, sedang dan rendah memiliki kemampuan berpikir kritis yang sama; (3) pada masing-masing model pembelajaran, siswa dengan self confidence tinggi, sedang dan rendah memiliki kemampuan berpikir kritis yang sama; (4) pada masing-masing kategori self confidence siswa, model pembelajaran Problem Posing memberikan kemampuan berpikir kritis yang lebih baik daripada Problem Solving.
\end{abstract}

Kata Kunci : Problem Posing, Problem Solving, Kemampuan Berpikir Kritis, Self Confidence

\begin{abstract}
The purpose of this study is to look at the comparison of Problem Posing and ProblemSolving learning models towards critical thinking skills in terms of students' Self Confidence in the function material. The research method is an experiment, in the form of a Quasi Experiment Design, with a $2 \times 3$ factorial design. The study population was all eighth-grade students of SMP Negeri 3 SanggauLedo TA. 2019/2020 which consisted of 3 classes, that used the Cluster Random Sampling technique. The data analysis technique of the variance analysis of the two cell roads was not the same and it was concluded that (1) the Problem Posing learning model provided better critical thinking skills than Problem Solving; (2) students with high, medium and low self-confidencehad the same critical thinking skills; (3) in each learning model, students with high, medium and low self-confidencehad the same critical thinking skills; (4) in each category of students' self-confidence, the Problem Posing learning model provided better critical thinking skills than Problem Solving.
\end{abstract}

Key Words : Problem Posing, Problem Solving, Critical Thinking Ability, Self Confidence

\section{PENDAHULUAN}

Ilmu universal yang mendasari perkembangan teknologi modern disebut dengan matematika dimana juga mempunyai peran dalam berbagai disiplin dan mengembangkan daya pikir manusia, sehingga menjadikan matematika adalah salah satu ilmu dasar yang mempelajari peranan penting dalam berbagai aspek kehidupan [1]. Salah satu pelajaran yang dianggap sulit menurut anggapan masyarakat umum pada setiap jenjang pendidikan adalah matematika. Ide-ide dan konsep-konsep yang abstrak berelasi dengan matematika. Proses yang harus dilalui dalam mempelajari matematika yaitu tidak boleh ada langkah/tahapan konsep yang dilewati, hal ini dikarenakan konsep matematika yang tersusun secara hierarki. Penyajian materi matematika harus disusun dengan struktur yang jelas dan disesuaikan dengan perkembangan intelektual siswa serta kemampuan prasyarat yang telah dimilikinya dan 
hendaknya dipelajari secara sistematis dan teratur. Akibatnya pembelajaran matematika yang dilaksanakan akan menjadi efektif dan efisien.Berdasarkan hasil observasi melalui wawancara terhadap guru SMP Negeri 3 Sanggau Ledo kemampuan siswa masih kurang dalam mengikuti pembelajaran matematika. Hal ini diketahui bahwa siswa masih kurang mampu menganalisis, menjelaskan pertanyaan dan jawaban, sehingga pencapaian hasil belajar siswa masih tergolong rendah. Padahal dalam menyampaikan materi sudah menggunakan salah satu model pembelajaran dan guru yang mengajar sudah berpengalaman dan sesuai dengan bidangnya. Walaupun siswa di kelas sudah diberikan pembelajaran dengan buku panduan LKS, akan tetapi kemampuan matematika siswa masih sangat kurang terutama kemampuan berpikir kritis siswa dalam menyelesaikan soal. Kemampuan berpikir kritis merupakan salah satu kemampuan berpikir yang penting untuk dimiliki oleh peserta didik. Hal ini dibuktikan dengan hasil uji coba soal peneliti pada salah satu kelas VIII diambil 3 orang siswa sebagai sample, yang disajikan pada Gambar berikut.

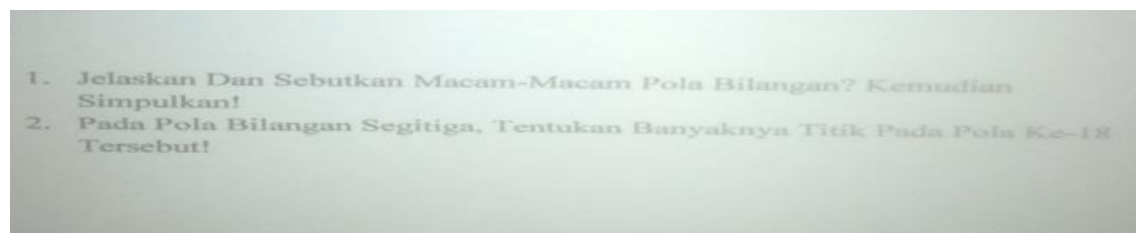

Gambar 1. Soal Kemampuan Berpikir Kritis Siswa

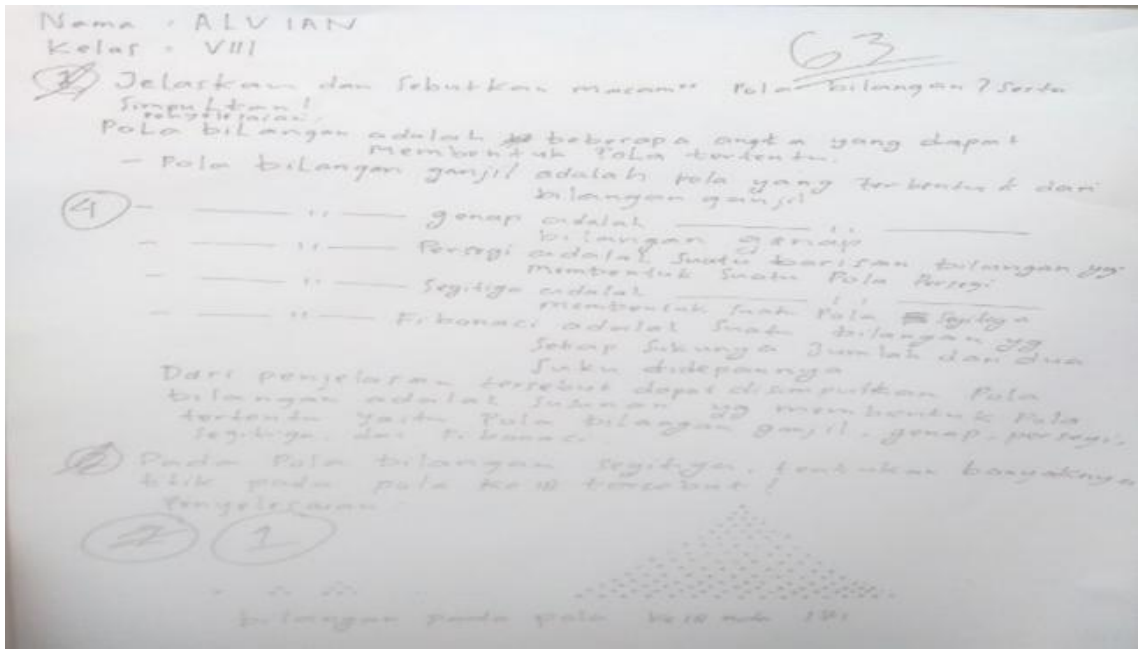

Gambar 2. Jawaban Kemampuan Berpikir Kritis Siswa

Berdasarkan jawaban pada Gambar 2, untuk soal pertama siswa sudah mampu memahami maksud dari soal tersebut dan mampu menyelesaikannya. Namun pada soal kedua dapat dilihat bahwa siswa kurang memahami maksud dari soal tersebut dan masih terdapat kekeliruan pada jawaban soal mengenai pola bilangan. Untuk soal nomor dua jawaban dari siswa, dapat dilihat bahwa siswa masih kurang dalam menentukan cara penyelesaian yang tepat, mereka kurang dapat menghubungkan materi dengan materi yang sebelumnya, masih ada siswa yang tidak menuliskan hal-hal yang diketahui dan ditanyakan dalam soal,siswa cenderung untuk tidak menuliskan langkah-langkah penyelesaian yang tidak lengkap dalam menjawab soal,masih ada siswa yang tidak melakukan pengecekan kembali jawabannya. Kebanyakan siswa kurang memahami soal sehingga terjadi 
kesalahan yang berakibat soal tidak terselesaikan dengan baik dan benar. Dari wawancara dan pembahasan soal tersebut, maka dapat disimpulkan bahwa kemampuan berpikir kritis siswa dalam mengerjakan soal matematika masih rendah.

Proses mental dalam menganalisis atau mengevaluasi informasi disebut dengan berpikir kritis [2]. Informasi tersebut bisa didapatkan dari hasil pengamatan, pengalaman, akal sehat atau komunikasi. Seorang peserta didik harus memiliki sikap yakin dan percaya akan kemampuan sendiri, sehingga terhindar dari rasa cemas dan ragu dalam rangka mengembangkan kemampuan matematika khususnya kemampuan berpikir kritis. Kepercayaan diri yang dimiliki setiap individu dalam memandang dirinya dengan mengacu pada konsep diri.

Pencapaian keberhasilan seseorang dalam memecahkan permasalahan yang sedang dihadapi dapat diberikan motivasi melalui kepercayaan diri. Semakin kuat semangat seseorang untuk menyelesaikan pekerjaannya selaras dengan semakin tinggi kepercayaannya terhadap kemampuan diri sendiri [3]. Kepercayaan diri merupakan suatu sikap atau perasaan yakin atas kemampuan diri sendiri sehingga orang yang bersangkutan tidak terlalu cemas dalam tindakan-tindakannya dapat merasa bebas untuk melakukan halhal yang disukainya, dan bertanggung jawab atas tindakannya, hangat dan sopan dalam berinteraksi dengan orang lain, dapat menerima dan menghargai orang lain, memiliki dorongan untuk berprestasi serta mengenal kelebihan dan kekurangan dirinya [3]. Kepercayaan terhadap kemampuan diri sendiri itulah yang mempengaruhi tingkat prestasi atau kinerja (performance) yang bersangkutan.
Untuk mengatasi hal tersebut, salah satunya dapat diterapkan dalam berbagai model pembelajaran. Ada dua model pembelajaran yang dapat digunakan yaitu Problem Posing dan Problem Solving. Problem Posing didefinisikan sebagai suatu kejadian ketika peserta didik terlibat dalam perumusan masalah yang diberikan dan juga ketika peserta didik memproduksi masalah baru atau pertanyaan [4]. Selanjutnya, pada problem posing ada pengalihan tanggung jawab dari guru ke siswadalam membuat kalimat pertanyaan matematika [5]. Siswapun terdorong menjadi aktif dalam proses pembelajaran matematika dikarenakan adanya pengalihan tanggung jawab ini. Problem Posing adalah pengajuan soal atau perumusan soal dari situasi yang diberikan dengan beberapa perubahan, berkaitan dengan syarat-syarat yang telah dipecahkan dalam rangka mencari alternatif pemecahan soal [6]. Sejalan dengan pendapat yang mengatakan bahwa pengajuan soal intinya meminta siswa untuk mengajukan masalah atau soal baru [7]. Lebih lanjut, manfaat mengajukan masalah, yaitu membantu siswa mengembangkan keyakinan dan kesukaan terhadap matematika. Kelebihan model problem posing di antaranya: (1) mendidik siswa berpikir kritis, (2) siswa aktif dalam pembelajaran, (3) belajar menganalisis suatu masalah, (4) mendidik anak percaya pada diri sendiri [8].

Problem solving adalah mencari atau menemukan cara penyelesaiannya (menemukan pola atau aturan) [8]. Ditambahkan pula bahwa suatu soal dapat dipakai sebagai sarana dalam pembelajaran dengan syarat antara lain; 1) siswa belum tahu cara menyelesaikan soal tersebut; 2) materi prasyarat sudah diperoleh siswa; 3 ) penyelesaian soal terjangkau oleh siswa; 4) siswa berkehendak menyelesaikan soal tersebut. Kelebihan model model problem solving di antaranya: (1) dapat melatih dan 
membiasakan siswa untuk menghadapi dan memecahkan masalah secara terampil, (2) dapat mengembangkan kemampuan berpikir siswa secara kreatif, (3) siswa mudah untuk dilatih memecahkan masalahnya, (4) berpikir dan bertindak kreatif, (5) menafsirkan dan mengevaluasi hasil pengamatan [8].

Ciri khas dari kedua model tersebut yaitu Problem Posing dan Problem Solving adalah model pembelajaran yang samasama menitikberatkan pada pemecahan masalah, siswa diajak untuk aktif, sehingga informasi tidak hanya diperoleh dari guru, tetapi siswa juga dituntut untuk mengkonstruksi sendiri pengetahuan baru mereka dengan informasi atau pengetahuan mereka sebelumnya. Pembelajaran yang melibatkan aktivitas problem posing dan problem solving dapat menimbulkan ketertarikan siswa terhadap matematika, meningkatkan kemampuan mereka dalam mengajukan masalah dan meningkatkan kemampuan belajar matematika mereka dengan baik [9]. Kemampuan siswa dalam mengajukan masalah yang berakibat meningkatnya kemampuan belajar matematika dipengaruhi oleh salah satu faktor yaitu kepercayaan diri (self confidence). Kepercayaan diri (self confidence) berfungsi penting untuk mengaktualisasikan potensi yangdimiliki oleh siswa [10]. Banyak masalah yang timbul karena siswa tidak memiliki kepercayaan diri. Keyakinan bahwa seseorang mampu menanggulangi suatu masalah dengan situasi terbaik dan dapat memberikan sesuatu yang menyenangkan bagi orang laindisebut self confidence (kepercayaan diri) [11]. Selanjutnya, percaya diri atau self confidence adalah aspek kepribadian yang penting pada diri seseorang [12].

Berdasarkan latar belakang tersebut, maka perlu dilakukan penelitian yang memperhatikan perbandingan dari model pembelajaran Problem Posingdan Problem Solving terhadap kemampuan berpikir kritis ditinjau dari Self Confidence siswa dalam materi fungsi di kelas VIII SMP Negeri 3 Sanggau Ledo.

\section{METODE}

Metode penelitian ini menggunakan penelitian eksperimen. Penelitian ini dilaksanakan di SMP Negeri 3 Sanggau Ledo tahun pelajaran 2019/2020. Bentuk penelitian ini adalah Quasi Experimental dengan desain faktorial $2 \times 3$. Populasi dalam penelitian ini adalah seluruh siswa kelas VIII SMP Negeri 3 Sanggau Ledo tahun pelajaran 2019/2020. Teknik pengambilan sampel adalah dengan teknik cluster random sampling, sehingga terpilih sample VIII A dan VIII B. Pengumpulan data pada penelitian ini menggunakan nilai ulangan harian, angket self confidence dan tes. Sebelum eksperimen, dilakukan uji keseimbangan terlebih dahulu untuk melihat apakah sampel memiliki kemampuan sama. Uji prasyarat untuk uji keseimbangan yang digunakan adalah uji normalitas dan uji homogenitas. Pengujian hipotesis penelitian, menggunakan analisis variansi dua jalan dengan sel tak sama dengan melakukan uji prasyarat untuk anava yaitu uji normalitas dan uji homogenitas terlebih dahulu. Jika diperlukan uji lanjut digunakan uji Scheffe [13].

\section{HASIL DAN PEMBAHASAN}

Hasil uji prasyarat untuk uji keseimbangan menyimpulkan bahwa semua sampel pada kelas eksperimen 1, eksperimen 2 berasal dari populasi yang berdistribusi normal dan populasi yang dibandingkan mempunyai variansi yang homogen. Pada uji keseimbangan diperoleh simpulan bahwa sampel berasal dari populasi yang mempunyai kemampuan yang sama dan layak dibandingkan. Pengujian hipotesis dilakukan untuk mengetahui apakah terdapat perbedaan 
pengaruh dari masing-masing model pembelajaran dan tingkat self confidence siswa terhadap kemampuan berpikir kritis. Semua sampel berasal dari populasi yang berdistribusi normal dan populasipopulasi yang dibandingkan mempunyai variansi yang homogeny yang merupakan hasil dan kesimpulan dari uji prasyarat. Hasil perhitungan analisis variansi dua jalan dengan sel tak sama dipaparkan dalam Tabel 1 berikut.

Tabel 1. Rangkuman Analisis Variansi Dua Jalan dengan Sel Tak Sama

\begin{tabular}{lcccccc}
\multicolumn{1}{c}{ Sumber } & $\boldsymbol{J K}$ & $\boldsymbol{D} \boldsymbol{R}$ & $\boldsymbol{R}$ & $\boldsymbol{F} \boldsymbol{o b s}$ & $\boldsymbol{F}_{\boldsymbol{\alpha}}$ & $\boldsymbol{P}$ \\
\hline Model Pembelajaran & 286,485 & 1 & 286,485 & 4,626 & 4,05 & $<0.05$ \\
$(\boldsymbol{A})$ & 11,856 & 2 & 5,928 & 0,096 & 3,19 & $>0.05$ \\
Self Confidence $(\boldsymbol{B})$ & 161,084 & 2 & 80,542 & 1,301 & 3,19 & $>0.05$ \\
Interaksi $(\boldsymbol{A B})$ & 2910,483 & 47 & 61,925 & - & - & - \\
Galat & 3369,908 & 52 & - & - & - & - \\
Total & & & & & & \\
\hline
\end{tabular}

Berdasarkan Tabel 1 menunjukkan bahwa $H_{O A}$ ditolak. Hal ini berarti terdapat perbedaan kemampuan berpikir kritis antara siswa yang menggunakan model pembelajaran problem posing dan siswa yang menggunakan model pembelajaran problem solving. Sementara itu, $H_{O B}$ diterima. Hal ini berarti tidak terdapat perbedaan kemampuan berpikir kritis siswa yang mempunyai self confidence belajar tinggi, sedang dan rendah. Sedangkan $H_{O A B}$ diterima, hal ini berarti tidak terdapat interaksi antara model pembelajaran dan self confidence belajar terhadap kemampuan berpikir kritis.

Berdasarkan hasil analisis variansi dua jalan dengan sel tak sama. Berikut ini disajikan rangkuman rerata sel dan rerata marginal pada Tabel 2 berikut.

Tabel 2. Deskripsi Data Rerata Sel dan Rerata Marginal

\begin{tabular}{ccccc}
\hline Model Pembelajaran & \multicolumn{3}{c}{ Self Confidence Siswa } & Rerata \\
\cline { 2 - 4 } & Tinggi & Sedang & Rendah & Marginal \\
\hline Problem Posing & 65,6 & 67,75 & 71,4 & 68,038 \\
Problem Solving & 64,33 & 64 & 61 & 63,444 \\
Rerata Marginal & 64,909 & 65,938 & 66,2 & - \\
\hline
\end{tabular}

Karena $H_{O A}$ ditolak, maka tidak perlu dilakukan uji komparasi rerata antar baris karena hanya terdapat dua model pembelajaran, jadi langsung dilihat pada rerata marginalnya. Berdasarkan Tabel 2 rataan marginal untuk model pembelajaran Problem Posing yaitu $(68,038)$ lebih besar dari rataan marginal model pembelajaran Problem Solving yaitu $(63,444)$, sehingga dapat disimpulkan bahwa kemampuan berpikir kritis dengan model pembelajaran Problem Posing lebih baik dari pada model pembelajaran Problem Solving ditinjau dari self confidence siswa pada materi fungsi. Hal ini menunjukkan adanya pengaruh model pembelajaran matematika terhadap kemampuan berpikir kritis siswa. Dalam hal ini, model pembelajaran Problem Posing lebih efektif dari pada pembelajaran Problem Solving pada materi fungsi. Hasil penelitian ini juga sesuai dengan hasil penelitian yang menunjukkan bahwa kemampuan komunikasi matematis siswa lebih baik jika diberikan model pembelajaran Problem Posing dengan pendekatan PMR dibandingkan model pembelajaran Problem Solving dengan pendekatan PMR [14]. Penelitian ini juga sejalan dengan penelitian yang memaparkan bahwa Problem Posing dengan setting kooperatif lebih efektif daripada pendekatan Problem Solving 
dengan setting kooperatif pada pembelajaran matematika ditinjau dari ketercapaian standar kompetensi, kemampuan berpikir kritis, dan kecerdasan emosional siswa [15].

Demikian pula dengan penelitian yang menyebutkan bahwa ada perbedaan pengaruh model problem solving dan problem posing terhadap kemampuan penyelesaian masalah IPA siswa [16]. Selain itu, hal ini mungkin disebabkan oleh banyak faktor, diantaranya yaitu siswa yang diberikan model pembelajaran Problem Posing saling membantu anggota kelompoknya dalam berdiskusi secara sungguh-sungguh. Selain itu juga, siswa didukung dengan persiapan yang baik dalam model pembelajaran Problem Posing, terutama dalam penyusunan Rencana Pelaksanaan Pembelajaran (RPP), dan Lembar Kerja Siswa (LKS).

Karena $H_{O B}$ diterima, jadi tidak perlu dilakukan uji komparasi rerata antar kolom. Berdasarkan hasil perhitungan pada Tabel 2, diperoleh simpulan bahwa siswa dengan tingkat self confidence tinggi, sedang dan rendah tidak memberikan efek yang berbeda terhadap kemampuan berpikir kritis siswa pada materi fungsi. Karena dilihat dari rerata marginal siswa dengan tingkat self confidence rendah lebih besar dari pada sedang, maka siswa dengan tingkat self confidence rendah menghasilkan kemampuan berpikir kritis yang lebih baik dibanding sedang. Siswa dengan tingkat self confidence sedang dan rendahlebih besar dari pada tinggi, maka siswa dengan tingkat self confidence sedang dan rendah menghasilkan kemampuan berpikir kritis yang lebih baik dibanding tinggi.

Dari hasil perhitungan analisis variansi dua jalan dengan sel tak sama diperoleh $F_{o b s}=$ $1,301<3,19=F_{\text {tabel }}$ maka $H_{O A B}$ diterima sehingga tidak perlu dilakukan uji pasca anava. Dengan diterimanya $H_{O A B}$ berarti tidak terdapat interaksi antara model pembelajaran dan self confidence siswa pada materi fungsi. Karena tidak terdapat interaksi antara model pembelajaran danself confidence, maka perbandingan antara model pembelajaran Problem Posing dan Problem Solving untuk setiap self confidence siswa mengikuti perbandingan marginalnya. Dengan tidak adanya interaksi mengakibatkan: a) Pada siswa dengan self confidence tinggi, pembelajaran dengan model pembelajaran Problem Posing menghasilkan kemampuan berpikir kritis lebih baik dari pada model pembelajaran Problem Solving. b) Pada siswa dengan self confidence sedang, pembelajaran dengan model pembelajaran Problem Posing menghasilkan kemampuan berpikir kritis lebih baik dari pada model pembelajaran Problem Solving. c) Pada siswa dengan self confidence rendah, pembelajaran dengan model pembelajaran Problem Posing menghasilkan kemampuan berpikir kritis lebih baik dari pada model pembelajaran Problem Solving. d) Pada model pembelajaran Problem Posing siswa dengan self confidence rendah menghasilkan kemampuan berpikir kritis lebih baik dari siswa dengan self confidencetinggi dan sedang. Siswa dengan self confidence sedang menghasilkan kemampuan berpikir kritis lebih baik dari siswa dengan self confidence tinggi. e) Pada model pembelajaran Problem Solving siswa dengan self confidence tinggi menghasilkan kemampuan berpikir kritis lebih baik dari siswa dengan self confidence sedang dan rendah. Siswa dengan self confidence sedang menghasilkan kemampuan berpikir kritis lebih baik dari siswa dengan self confidence rendah.

\section{SIMPULAN}

Berdasarkan pengolahan data dan pembahasan dapat diketahui bahwa komparasi model pembelajaran Problem 
Posing pada materi fungsi ditinjau dari self confidence siswa kelas VIII SMP Negeri 3Sanggau Ledo memberikan dampak positif yang lebih baik dibandingkan dengan pembelajaran Problem Solving. Secara umum dapat disimpulkan sebagai berikut:(1) model pembelajaran Problem Posing memberikan kemampuan berpikir kritis yang lebih baik daripada Problem Solving; (2) siswa dengan self confidence tinggi, sedang dan rendah memiliki kemampuan berpikir kritis yang sama; (3) pada masing-masing model pembelajaran, siswa dengan self confidence tinggi, sedang dan rendah memiliki kemampuan berpikir kritis yang sama; (4) pada masingmasing kategori self confidence siswa, model pembelajaran Problem Posing memberikan kemampuan berpikir kritis yang lebih baik daripada Problem Solving.

\section{DAFTAR PUSTAKA}

[1] Y. Darma dan I. Sujadi. "Strategi Heuristik dengan Pendekatan Metakognitif dan Investigasi terhadap Kemampuan Pemecahan Masalah Matematis Ditinjau dari Kreativitas Siswa Madrasah Aliyah”. J. Pendidik. MIPA, vol. 15, no. 2, pp. 110-119, 2014.

[2] E. Ariyati. "Pembelajaran Berbasis Praktikum untuk Meningkatkan Kemampuan Berpikir Kritis Mahasiswa". J. Pendidik. Mat. dan IPA, vol. 1, no. 2, pp. 1-12, 2012.

[3] H. Hendriana, E. E. Rohaeti, dan U. Sumarmo. Hard Skills and Soft Skills Matematik Siswa. Bandung: PT Refika Aditama, 2017.

[4] N. I. Fajariyah, Y. L. Sukestiyarno, dan I. Junaedi. "Efektivitas Pembelajaran Matematika dengan Metode Problem Posing Berbasis Pendidikan Karakter". Unnes J. Math. Educ., vol. 1, no. 1, 2012.

[5] U. D. Susiaty. "Korelasi antara Kemampuan Awal dengan Kemampuan Akhir Siswa melalui
Within-Solution Posing pada Materi Perbandingan". J. Pendidik. Inform. dan Sains, vol. 5, no. 2, pp. 260-270, 2016.

[6] D. Daryati, Nugraha, dan N. Sutarni. "Pengaruh Penggunaan Metode Problem Posing terhadap Kemampuan Memecahkan Masalah". J. Pendidik. Ilmu Sos. JPIS, vol. 27, no. 1, pp. 31-42, 2018.

[7] E.Siswono. Pembelajaran Matematika Berbasis Pengajuan dan Pemecahan Masalah. Bandung: PT. Remaja Rosdakarya, 2015.

[8] A. Shoimin. Model Pembelajaran INOVATIF dalam Kurikulum 2013. Yogyakarta: Ar-Ruzz, 2014.

[9] H. Hodiyanto dan U. D. Susiaty. "Peningkatan Kemampuan

Pembuktian Matematis Melalui Model Pembelajaran Problem Posing". MaPan, vol. 6, no. 1, pp. 128-137, 2018.

[10] S. Nurkholifah, Toheri, dan W. Winarso. "Hubungan antara Self Confidence dengan Kemampuan Berpikir Kritis Siswa dalam Pembelajaran Matematika". Pendidik. Mat., vol. 08, no. 01, pp. 58-66, 2018.

[11] A. Martyanti. "Membangun SelfCofidence Siswa dalam Pembelajaran Matematika". Penguatan Peran Matematika dan Pendidikan Matematika untuk Indonesia, pp. 978-979, 2013.

[12] A. Syam dan Amri. "Pengaruh Kepercayaan Diri (Self Confidence) Berbasis Kaderisasi Imm terhadap Prestasi Belajar Mahasiswa (Studi Kasus di Program Studi Pendidikan Biologi Fakultas Keguruan dan Ilmu Pendidikan Universitas Muhammadiyah Parepare)". J. Biotek, vol. 5, pp. 87-102, 2017.

[13] Budiyono. Statistik untuk Penelitian. Surakarta: UNS Press, 2009.

[14] Hodiyanto, Budiyono, dan I. Slamet, 
"Eksperimentasi Model

Pembelajaran Problem Posing dan Problem Solving dengan Pendekatan PMR terhadap Prestasi Belajar dan Kemampuan Komunikasi Matematiks Ditinjau dari Kreativitas Siswa Kelas VIII SMP Negeri di Kabupaten Sukoharjo". $J$. Pembelajaran Mat., vol. 4, no. 2, 2016.

[15] W. N. Shanti dan A. M. Abadi. "Keefektifan Pendekatan Problem
Solving dan Problem Posing dengan Setting Kooperatif dalam Pembelajaran Matematika". J. Ris. Pendidik. Mat., vol. 2, no. 1, pp. 121, 2015.

[16] I. Rosidi. "Perbandingan Problem Solvingdan Problem Posing Ditinjau dari Kreativitas Verbal terhadap Kemampuan Penyelesaian Masalah Ipa". Educ. Hum. Dev. J., vol. 5, no. 1, pp. 105-114, 2019. 